\title{
Research in the Works
}

A Publication of the Systems and Psychosocial Advances Research Center

A Massachusetts Department of Mental Health Research Center of Excellence

\section{Improving the Outcomes of Transition Age Youth with Psychiatric Disabilities through the Adoption and Use of Best Practice Transition Planning}

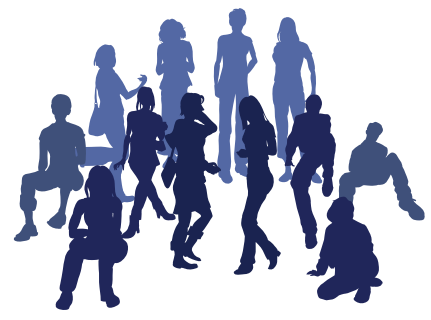

Improving the educational attainment and outcomes for youth with emotional and behavioral disturbances (EBD) should be a high priority goal for policy makers, school systems, and researchers. Students with EBD drop out of high school more than any other group of students with disabilities. ${ }^{1-2}$ A truncated education is correlated with lower wages, lower employment rates, and poorer health. ${ }^{3-5}$ Youth with EBD also participate in postsecondary education less frequently and have lower rates of postschool employment than many other categories of students with disabilities. ${ }^{6-9}$ Research has shown that the poor outcomes experienced by this vulnerable group are worsened by the lack of best practice transition planning for students with EBD as they move to postsecondary life. Transition planning is where goals and services are outlined for students with EBD enrolled in special education as part of an Individualized Education Program.

\section{Project Goal and Outcomes:}

The goal of the newly funded Translating Evidence to Support Transitions (TEST) grant is to increase the use and adoption of research-based best practices in transition planning services for high school students with EBD receiving special education services. TEST outcomes include the development of guides and curricula for practicing and implementing best practices in transition planning. All TEST activities will be built on an implementation science framework to promote the integration of research evidence into transition planning practices. ${ }^{10-11}$ TEST will be guided by knowledge translation principles to ensure that findings will reach the individuals and organizations that can put the guides and curricula into practice. ${ }^{12-13}$ Over the five year project timeline, data and feedback will be collected at each step in order to continually improve TEST materials.

\section{Project Activities Include:}

1. Developing research-informed materials and procedures for use by transition planning teams that are tailored to students with EBD;

2. Pilot-testing procedures and materials, in partnership with implementation teams, in a South Carolina school district to develop and finalize TEST procedures and materials;

3. Providing implementation support and technical assistance to transition teams in one state, to be determined, which will result in a TEST implementation guide;

4. Presenting TEST best practices and implementation guides and curricula at a national capacity building institute for high school special education transition planning teams; and

5. Disseminating TEST materials nationally.

Project Personnel:

UMMS project personnel include Marsha Ellison, $\mathrm{PhD}$ (PI); Kathleen Biebel, PhD (Co-PI); Sloan Huckabee, PhD, Lauren Davis, BS, and Laura Golden, BA. Project partners include the American Institutes for Research (AIR), the National Technical Assistance Center on Transition (NTACT), and SRI International.

TEST is funded by the National Institute on Disability, Independent Living, and Rehabilitation Research (NIDILRR; grant number 90DP0080-01-00). NIDILRR is a Center within the Administration for Community Living (ACL), Department of Health and Human Services (HHS). The contents of this Research in the Works publication do not necessarily represent the policy of NIDILRR, ACL, HHS, and you should not assume endorsement by the Federal Government. 


\section{References}

1. Duchnowski, A., \& Kutash, K. (2011). School reform and mental health services for students with emotional disturbances educated in urban schools. Education and treatment of children, 34(3), 323-346.

2. NLTS2. (2002). NLTS2 data brief: Introducing the NLTS2. A report from the National Longitudinal Transition Study-2.

3. Pleis, J. R., Ward, B. W., \& Lucas, J. W. (2010). Vital and health statistics: Summary health statistics for US adults: National health interview survey, 2009 (Vol. 10). Hyattsville, MD: U.S. Department of Health and Human Services, Centers for Disease Control and Prevention, National Center for Health Statistics.

4. Rouse, C. E. (2007). Quantifying the costs of inadequate education: Consequences of the labor market. Washington, DC: Brookings Institution Press.

5. U.S. Department of Labor, Bureau of Labor Statistics. (2010). Tabulations.

6. Anderson, J. A., Kutash, K., \& Duchnowski, A. J. (2001). A comparison of the academic progress of students with EBD and students with LD. Journal of Emotional and Behavioral Disorders, 9(2), 106-115. doi: $10.1177 / 106342660100900205$

7. Lane, K. L., Carter, E. W., Pierson, M. R., \& Glaeser, B. C. (2006). Academic, social, and behavioral characteristics of high school students with emotional disturbances or learning disabilities. Journal of Emotional and Behavioral Disorders, 14(2), 108-117.

8. Newman, L., Wagner, M., Knokey, A. M., Marder, C., Nagle, K., Shaver, D., \& Wei, X. (2011). The post-high school outcomes of young adults with disabilities up to 8 years after high school: A report from the National Longitudinal Transition Study-2 (NLTS2). Menlo Park, CA: SRI International.

9. Wagner, M., \& Davis, M. (2006). How are we preparing students with emotional disturbances for the transition to young adulthood? Findings from the National Longitudinal Transition Study-2. Journal of Emotional and Behavioral Disorders, 14(2), 86-98.

10. Fixsen, D. L., Naoom, S. F., Blase, K. A., Friedman, R. M., \& Wallace, F. (2005). Implementation research: A synthesis of the literature. The National Implementation Research Network.

11. Metz, A., Naoom, S. F., Halle, T., \& Bartley, L. (2015). An intergrated stage-based framework for implementation of early childhood programs and systems (U. S. D. o. H. a. H. Services, Trans.) OPRE Research Brief. Washington, DC.

12. Estabrooks, C. A., Thompson, D. S., Lovely, J. J. E., \& Hofmeyer, A. (2006). A guide to knowledge translation theory. Journal of Continuing Education in the Health Professions, 26(1), 25-36. doi: 10.1002/chp.48

13. Gibbons, M. B. (2008). Why is knowledge translation important? FOCUS: A Technical Brief from the National Center for the Dissemination of Disability Research. Retrieved from http://www.ncddr.org/kt/products/focus/ focus 21 